\title{
EFEKTIVITAS PENDEKATAN OPEN-ENDED DAN CTL DITINJAU DARI BERPIKIR KREATIF SISWA KELAS VII
}

\author{
Yeni Rahmawati E.S. \\ Pendidikan Matematika FKIP Universitas Muhammadiyah Metro \\ yeni.rahmawati1988@yahoo.com
}

\begin{abstract}
This research aimed to describe the effectiveness of the open-ended and CTL approach in terms of creative thinking. This research was quasi-experimental study design with nonequivalent pretest-posttest design goup. The research population was all students in class VII SMP Negeri 1 Sekampung which consisted of five classes. The research sample consisted of two classes is determined randomly. First experimental group was treated the open-ended and experimental group II were treated CTL approach. The one sample t-test carried out to investigate the effectiveness of the open-ended and CTL approach. Data collection techniques used were tests. Engineering tests used to measure student creative thinking on basic competencies: 1) identify the properties of a rectangle, square, trapezoid, parallelogram, rhombus and a kite; 2) calculate the circumference and area of a rectangle up and use it in problem solving both before and after treatment. The results of the research show that the open-ended and CTL approach is effective in terms of creative thinking.
\end{abstract}

Keywords: open-ended, contextual teaching and learning, creative thinking

\section{PENDAHULUAN}

Kreativitas yang merupakan hasil dari berpikir kreatif menjadi salah satu penentu kesuksesan hidup individu. Hal ini seperti yang diungkapkan oleh Alexander (Mahmudi, 2008) bahwa kesuksesan hidup individu sangat ditentukan oleh kemampuannya untuk secara kreatif menyelesaikan masalah, baik dalam skala besar maupun kecil. Dengan semakin ketatnya persaingan global saat ini, maka sejak dini siswa perlu dibekali kemampuan berpikir kreatif. Hal ini sesuai dengan Permendiknas Nomor 22 Tahun 2006 yang menyebutkan bahwa mata pelajaran matematika perlu diberikan kepada semua peserta didik mulai dari sekolah dasar untuk membekali peserta didik dengan kemampuan berpikir logis, analitis, sistematis, kritis, dan kreatif, serta kemampuan bekerjasama.

Kemampuan berpikir kreatif merupakan kemampuan seseorang dalam menyelesaikan masalah 
dengan cara yang berbeda atau cara baru. McGregor (2007) mendefinisikan creative thingking is the generation or suggestion of a unique or alternative perspective, the production of an innovative design or a new approach to a problem or artistic challenge. Berpikir kreatif adalah berpikir yang mengarah kepada pemerolehan wawasan baru atau perspektif baru, menghasilkan cara baru atau pendekatan baru dalam memahami masalah atau sesuatu yang menantang. Sedangkan Torrance (Wang, 2011) mendefinisikan creative thinking as the ability to sense problems, make guesses, generate new ideas, and communicate results. Berpikir kreatif sebagai kemampuan untuk memecahkan masalah, membuat dugaan, menghasilkan ide-ide baru, dan mengkomunikasikan hasil. Dengan kemampuan berpikir kreatif yang dibekali kepada siswa, diharapkan siswa dapat memecahkan masalah dengan memberikan ide-ide baru yang bermanfaat bagi orang lain.

Berdasarkan hasil TIMSS diperoleh informasi bahwa kemampuan siswa SMP di Indonesia dalam menyelesaikan soal-soal tidak rutin sangat lemah, meskipun cukup baik dalam menyelesaikan soal-soal tentang fakta dan prosedural. Hal ini menunjukkan bahwa kemampuan siswa SMP di Indonesia dalam menyelesaikan masalah yang melibatkan proses berpikir tingkat tinggi masih relatif rendah, salah satunya kemampuan berpikir kreatif.

Selama ini pembelajaran di sekolah masih bersifat pasif. Pembelajarannya masih bersifat teacher centered. Guru masih memegang peranan yang dominan dalam pembelajaran. Laila (2009) memaparkan bahwa guru masih beranggapan bahwa pendekatan konvensional yang selama ini diterapkan adalah pendekatan yang paling mudah untuk diterapkan di sekolah. Metode yang sering digunakan oleh para guru adalah metode ceramah. Selain itu, ketika latihan atau ulangan harian soalsoal yang diberikan mengarahkan siswa pada satu jawaban benar. Pembelajaran seperti ini masih diterapkan di SMPN 1 Sekampung Lampung Timur.

Perlu adanya perlakuan khusus agar proses pembelajaran matematika tidak lagi menjadi pelajaran yang monoton. Penting bagi guru untuk memilih pendekatan pembelajaran yang sesuai dengan kebutuhan belajar siswa. Pemilihan dan penggunaan pendekatan pembelajaran harus bisa mengarahkan siswa belajar lebih aktif sehingga dapat mengaplikasikannya dalam kehidupan sehari-hari. Selain itu, pendekatan pembelajaran yang dipilih perlu menyajikan masalahmasalah nonrutin atau masalahmasalah terbuka serta memberikan kesempatan yang luas kepada siswa untuk menggali kemampuan 
dan pengalaman yang telah dimiliki sehingga tercapai hasil belajar siswa yang optimal.

Alternatif pendekatan pembelajaran yang dapat digunakan oleh guru adalah pendekatan open-ended dan pendekatan contextual teaching and learning (CTL). Shimada (1997) menjelaskan bahwa pendekatan open-ended adalah pendekatan pembelajaran yang menyajikan suatu permasalahan yang memiliki metode atau penyelesaian yang benar lebih dari satu, bukan meminta siswa mengarah pada satu jawaban benar melainkan lebih berfokus pada cara siswa untuk sampai pada penyelesaian masalah. Pendekatan open-ended memberi kesempatan kepada siswa untuk memperoleh pengetahuan maupun pengalaman untuk menemukan, mengenali, dan memecahkan masalah tertutup ataupun terbuka dengan banyak cara sesuai dengan kemampuan yang telah dimiliki. Tujuan dari pembelajaran open ended adalah untuk membantu mengembangkan kegiatan kreatif dan pola pikir matematis siswa melalui problem solving secara simultan.Hal ini sesuai dengan Permendiknas Nomor 22 Tahun 2006 yang menyebutkan bahwa pendekatan pemecahan masalah merupakan fokus dalam pembelajaran matematika yang mencakup masalah tertutup dengan solusi tunggal, masalah terbuka dengan solusi tidak tunggal, dan masalah dengan berbagai cara penyelesaian. Ini menunjukkan bahwa guru sangat perlu memberikan situasi belajar dimana siswa diberi kesempatan untuk mengembangkan kemampuannya dalam menyelesaikan masalah yang memiliki banyak cara penyelesaiannya dan juga banyak jawaban yang benar.

Pembelajaran

CTL

merupakan pendekatan pembelajaran yang tidak menuntut siswa menghafalkan rumus-rumus. Siswa lebih diarahkan untuk membuat hubungan antara yang dipelajari dengan aplikasinya dalam kehidupan nyata mereka. Pendekatan CTL mengharapkan siswa belajar melalui mengalami bukan menghapal. Johnson (2002) menjelaskan bahwa CTL merupakan suatu proses pengajaran yang bertujuan untuk membantu siswa memahami materi pelajaran yang sedang mereka pelajari dengan menghubungkan pokok materi pelajaran dengan penerapannya dalam kehidupan sehari-hari. Dengan demikian, diharapkan guru mampu mengaitkan setiap materi pelajaran dengan konteks kehidupan sehari-hari siswa termasuk dalam pembelajaran matematika sehingga hasil pembelajaran lebih bermakna bagi siswa. Hal ini sesuai dengan Permendiknas Nomor 22 Tahun 2006 yang menyebutkan bahwa dalam setiap kesempatan, pembelajaran matematika 
hendaknya dimulai dengan pengenalan masalah yang sesuai dengan situasi (contextual problem).

Berdasarkan pemaparan di atas, penelitian ini bertujuan untuk mengetahui efektivitas pendekatan open-ended dan CTL ditinjau dari berpikir kreatif siswa.

\section{METODE PENELITIAN}

Jenis penelitian ini adalah penelitian eksperimen semu. Penelitian ini melibatkan dua kelompok yaitu kelompok eksperimen I dan kelompok eksperimen II. Kelompok eksperimen I diberi perlakuan dengan pendekatan open-ended inovatif dan kelompok eksperimen II diberikan perlakuan dengan pendekatan CTL. Desain penelitian yang digunakan adalah pretest-posttest nonequivalent group design. Pada setiap kelompok dilakukan pretest dan posttest.

Penelitian ini dilaksanakan di SMPN 1 Sekampung Lampung Timur. Waktu yang dipergunakan pada penelitian adalah semester genap tahun pelajaran 2012/2013 dari bulan April sampai Mei 2013 sebanyak 13 kali pertemuan.

Populasi dalam penelitian ini adalah seluruh siswa kelas VII SMPN 1 Sekampung Tahun Pelajaran 2012/2013 yang terdiri dari 5 kelas. Teknik pengambilan sampel menggunakan teknik simple random sampling. Sampel yang diperoleh dan digunakan dalam penelitian ini adalah kelas $\mathrm{VII}^{3}$ dan $\mathrm{VII}^{4}$. Kelas $\mathrm{VII}^{3}$ terpilih untuk diberi perlakuan dengan pendekatan CTL dan kelas VII terpilih untuk diberi perlakuan dengan pendekatan Open-Ended.

Dalam penelitian ini data diperoleh langsung oleh peneliti dengan memberikan pretest pada kedua kelompok sebelum diberikan perlakuan dan postest setelah diberikan perlakuan. Untuk instrumen yang digunakan dalam penelitian ini adalah instrumen tes. Instrumen tes yang digunakan untuk mengukur berpikir kreatif pada penelitian ini berupa tes tertulis essai.

Data berpikir kreatif matematika diperoleh melalui pengukuran dengan instrumen tes yang berbentuk uraian yang berjumlah 3 item. Skor yang diperoleh selanjutnya dikonversi sehingga menjadi nilai dengan rentang 0 sampai 100. Skor minimum ideal adalah 0 dan skor maksimal ideal adalah 100. Skor tersebut kemudian digolongkan dalam kriteria yang tersaji pada Tabel 1. Variabel berpikir kreatif dikatakan efektif jika skor yang diperoleh termasuk dalam kriteria cukup kreatif, kreatif dan sangat kreatif. 
Tabel 1. Kriteria Berpikir kreatif

\begin{tabular}{|c|c|c|}
\hline Interval & $\begin{array}{c}\text { Interval Skor } \\
\text { Berpikir Kreatif }\end{array}$ & Kriteria \\
\hline$M i+1,5 S i<X \leq M i+3 S i$ & $74,90<X \leq 100$ & Sangat kreatif \\
\hline$M i+0,5 S i<X \leq M i+1,5 S i$ & $58,30<X \leq 74,90$ & Kreatif \\
\hline$M i-0,5 S i<X \leq M i+0,5 S i$ & $41,70<X \leq 58,30$ & Cukup kreatif \\
\hline$M i-1,5 S i<X \leq M i-0,5 S i$ & $25,10<X \leq 41,70$ & Kurang kreatif \\
\hline$M i-3 S i \leq X \leq M i-1,5 S i$ & $0 \leq X \leq 25,10$ & Tidak kreatif \\
\hline
\end{tabular}

Keterangan:

$X \quad$ : total skor aktual

$M i: \frac{1}{2}$ (skor maksimal ideal + skor minimal ideal)

Si : $\frac{1}{6}$ (skor maksimal ideal - skor minimal ideal)

(Saifuddin Azwar, 2011)

\section{HASIL PENELITIAN DAN PEMBAHASAN}

Guru membagi siswa menjadi 7 kelompok dengan masingmasing kelompok beranggotakan 4 siswa. Selanjutnya guru memberikan LKS pada tiap siswa. Secara umum, untuk kedua kelas eksprimen pengelolaan kelas dilaksanakan dengan dua tahap. Tahap pertama, siswa diminta untuk menyelesaikan soal-soal yang ada pada LKS secara individu. Tahap kedua, siswa bersama teman kelompok mendiskusikan hasil temuan masing-masing siswa untuk menarik kesimpulan. Selanjutnya, guru memanggil salah satu siswa dari kelompok tertentu untuk mempresantasikan hasil kelompok. Diakhir pembelajaran siswa mengerjakan latihan soal.

Data berpikir kreatif matematika diperoleh dari kedua kelas eksperimen baik sebelum maupun setelah diberi perlakuan. Secara ringkas hasil berpikir kreatif matematika pada kedua kelas eksperimen tersaji pada Tabel 2 berikut.

Tabel 2. Deskripsi Data Berpikir Kreatif pada Pretest dan Posttest

\begin{tabular}{|c|c|c|c|c|}
\hline \multirow{2}{*}{ Deskripsi } & \multicolumn{2}{|c|}{ Kelas open-ended } & \multicolumn{2}{c|}{ Kelas CTL } \\
\cline { 2 - 5 } & Pretest & Posttest & Pretest & Posttest \\
\hline Rata-rata & 18,94 & 58,76 & 25,09 & 52,57 \\
\hline Nilai minimum teoritik & 0 & 0 & 0 & 0 \\
\hline Nilai minimum siswa & 5,55 & 30,55 & 11,11 & 25,00 \\
\hline Nilai maksimum teoritik & 100 & 100 & 100 & 100 \\
\hline Nilai maksimum siswa & 55,55 & 83,33 & 50,00 & 88,88 \\
\hline Standar deviasi & 11,64 & 12,91 & 9,45 & 15,74 \\
\hline Varians & 135,49 & 166,73 & 89,43 & 247,99 \\
\hline
\end{tabular}


Berdasarkan Tabel 2, ratarata pretest berpikir kreatif siswa pada kelas open-ended menggunakan pertanyaanpertanyaan inovatif adalah 18,94. Hasil tersebut menunjukan ratarata pretest berpikir kreatif siswa berada pada interval $0 \leq X \leq$ 25,10 yang termasuk dalam kriteria tidak kreatif. Rata-rata pretest berpikir kreatif siswa pada kelas CTL adalah 25,09. Hasil tersebut menunjukan rata-rata pretest berpikir kreatif siswa berada pada interval $0 \leq X \leq$ 25,10 yang termasuk dalam kriteria tidak kreatif. Dari kedua kelas yang digunakan dalam penelitian ini, nilai tertinggi pretest berpikir kreatif yang dicapai siswa adalah 55,55 dan nilai terendah adalah 5,55.

Berdasarkan Tabel 2, ratarata posttest berpikir kreatif siswa pada kelas open-ended menggunakan pertanyaanpertanyaan inovatif adalah 58,76. Hasil tersebut menunjukan ratarata posttest berpikir kreatif siswa berada pada interval $58,30<X \leq$ 74,90 yang termasuk dalam kriteria kreatif. Rata-rata posttest berpikir kreatif siswa pada kelas CTL adalah 52,57. Hasil tersebut menunjukan rata-rata posttest berpikir kreatif siswa berada pada interval $41,70<X \leq 58,76$ yang termasuk dalam kriteria cukup kreatif. Dari kedua kelas yang digunakan dalam penelitian ini, nilai tertinggi posttest berpikir kreatif yang dicapai siswa adalah 88,88 dan nilai terendah adalah 25 . Jika dilakukan perbandingan antara rata-rata pretest dan posttest, terlihat bahwa pada kedua kelas terjadi peningkatan rata-rata berpikir kreatif matematika.

Penentuan kriteria berpikir kreatif awal dan akhir siswa pada kelas open-ended dan kelas CTL ditentukan sebagaimana pada Tabel 1 sehingga diperoleh hasil berpikir kreatif awal (pretest) dan akhir (posttest) siswa seperti yang tersaji pada Tabel 3, Tabel 4, Tabel 5, dan Tabel 6 .

Tabel 3. Frekuensi dan Persentase Berpikir Kreatif Awal Siswa pada Kelas Open-Ended

\begin{tabular}{|c|c|c|c|}
\hline Skor $(X)$ & Frekuensi & Persentase & Kriteria \\
\hline $74,90<X \leq 100$ & 0 & $0 \%$ & Sangat kreatif \\
\hline $58,30<X \leq 74,90$ & 0 & $0 \%$ & Kreatif \\
\hline $41,70<X \leq 58,30$ & 1 & $3,57 \%$ & Cukup kreatif \\
\hline $25,10<X \leq 41,70$ & 7 & $25 \%$ & Kurang kreatif \\
\hline $0 \leq X \leq 25,10$ & 20 & $71,43 \%$ & Tidak kreatif \\
\hline
\end{tabular}


Berdasarkan Tabel 3 di atas, siswa yang berpikir kreatif pada kriteria sangat kreatif tidak ada dengan besar persentasenya adalah $0 \%$, siswa yang berpikir kreatif pada kriteria kreatif tidak ada dengan besar persentasenya adalah $0 \%$, siswa yang berpikir kreatif pada kriteria cukup kreatif ada 1 siswa dengan besar persentasenya adalah $3,57 \%$, siswa yang berpikir kreatif pada kriteria kurang kreatif ada 7 siswa dengan besar persentasenya adalah $25 \%$, dan siswa yang berpikir kreatif pada kriteria tidak kreatif ada 20 siswa dengan besar persentasenya adalah $71,43 \%$. Dapat disimpulkan bahwa berpikir kreatif awal siswa pada kelas open-ended sebagian besar masuk dalam kriteria tidak kreatif.

Tabel 4. Frekuensi dan Persentase Berpikir Kreatif Awal Siswa pada Kelas CTL

\begin{tabular}{|c|c|c|c|}
\hline Skor $(X)$ & Frekuensi & Persentase & Kriteria \\
\hline $74,90<X \leq 100$ & 0 & $0 \%$ & Sangat kreatif \\
\hline $58,30<X \leq 74,90$ & 0 & $0 \%$ & Kreatif \\
\hline $41,70<X \leq 58,30$ & 1 & $3,57 \%$ & Cukup kreatif \\
\hline $25,10<X \leq 41,70$ & 12 & $42,86 \%$ & Kurang kreatif \\
\hline $0 \leq X \leq 25,10$ & 15 & $53,57 \%$ & Tidak kreatif \\
\hline
\end{tabular}

Berdasarkan Tabel 4 di atas, siswa yang berpikir kreatif pada kriteria sangat kreatif tidak ada dengan besar persentasenya adalah $0 \%$, siswa yang berpikir kreatif pada kriteria kreatif tidak ada dengan besar persentasenya adalah $0 \%$, siswa yang berpikir kreatif pada kriteria cukup kreatif ada 1 siswa dengan besar persentasenya adalah $3,57 \%$, siswa yang berpikir kreatif pada kriteria kurang kreatif ada 12 siswa dengan besar persentasenya adalah $42,86 \%$, dan siswa yang berpikir kreatif pada kriteria tidak kreatif ada 15 siswa dengan besar persentasenya adalah $53,57 \%$. Dapat disimpulkan bahwa berpikir kreatif awal siswa pada kelas CTL sebagian besar masuk dalam kriteria tidak kreatif.

Tabel 5. Frekuensi dan Persentase Berpikir Kreatif Akhir Siswa pada Kelas Open-Ended

\begin{tabular}{|c|c|c|c|}
\hline Skor $(X)$ & Frekuensi & Persentase & Kriteria \\
\hline $74,90<X \leq 100$ & 3 & $10,71 \%$ & Sangat kreatif \\
\hline $58,30<X \leq 74,90$ & 11 & $39,29 \%$ & Kreatif \\
\hline $41,70<X \leq 58,30$ & 12 & $42,86 \%$ & Cukup kreatif \\
\hline $25,10<X \leq 41,70$ & 2 & $7,14 \%$ & Kurang kreatif \\
\hline $0 \leq X \leq 25,10$ & 0 & $0 \%$ & Tidak kreatif \\
\hline
\end{tabular}


Berdasarkan Tabel 5 di atas, siswa yang berpikir kreatif pada kriteria sangat kreatif ada 3 siswa dengan besar persentasenya adalah $10,71 \%$, siswa yang berpikir kreatif pada kriteria kreatif ada 11 siswa dengan besar persentasenya adalah 39,29\%, siswa yang berpikir kreatif pada kriteria cukup kreatif ada 12 siswa dengan besar persentasenya adalah $42,86 \%$, siswa yang berpikir kreatif pada kriteria kurang kreatif ada 2 siswa dengan besar persentasenya adalah $7,14 \%$, dan siswa yang berpikir kreatif pada kriteria tidak kreatif tidak ada dengan besar persentasenya adalah 0\%. Dapat disimpulkan bahwa berpikir kreatif akhir siswa pada kelas open-ended menggunakan pertanyaanpertanyaan inovatif sebagian besar dalam kriteria cukup kreatif.

Tabel 6. Frekuensi dan Persentase Berpikir Kreatif Akhir Siswa pada Kelas CTL

\begin{tabular}{|c|c|c|c|}
\hline Skor $(X)$ & Frekuensi & Persentase & Kriteria \\
\hline $74,90<X \leq 100$ & 2 & $7,14 \%$ & Sangat kreatif \\
\hline $58,30<X \leq 74,90$ & 7 & $25 \%$ & Kreatif \\
\hline $41,70<X \leq 58,30$ & 14 & $50 \%$ & Cukup kreatif \\
\hline $25,10<X \leq 41,70$ & 3 & $10,72 \%$ & Kurang kreatif \\
\hline $0 \leq X \leq 25,10$ & 2 & $7,14 \%$ & Tidak kreatif \\
\hline
\end{tabular}

Berdasarkan Tabel 6 di atas, siswa yang berpikir kreatif pada kriteria sangat kreatif ada 2 siswa dengan besar persentasenya adalah $7,14 \%$, siswa yang berpikir kreatif pada kriteria kreatif ada 7 siswa dengan besar persentasenya adalah $25 \%$, siswa yang berpikir kreatif pada kriteria cukup kreatif ada 14 siswa dengan besar persentasenya adalah $50 \%$, siswa yang berpikir kreatif pada kriteria kurang kreatif ada 3 siswa dengan besar persentasenya adalah $10,72 \%$, dan siswa yang berpikir kreatif pada kriteria tidak kreatif ada 2 siswa dengan besar persentasenya adalah
7,14\%. Dapat disimpulkan bahwa berpikir kreatif akhir siswa pada kelas CTL sebagian besar masuk dalam kriteria cukup kreatif.

Perhitungan one sample $t$ test menggunakan taraf signifikansi 0,05 dengan derajat bebas adalah $28-1=$ 27. Kriteria keputusannya adalah $\mathrm{H}_{\mathrm{o}}$ ditolak jika $t_{\text {hitung }}>$ $t_{(0,05 ; 27)}=1,70 . \quad$ Pengujian keefektifan dilakukan dengan bantuan SPSS 19 for window. Adapun hasil uji one sample t-test disajikan pada Tabel 7 berikut: 
Tabel 7. Hasil Uji Keefektifan Pendekatan Open-Ended dan CTL

\begin{tabular}{|c|c|c|c|c|}
\hline Variabel & Kelas & $\mathrm{t}_{\text {hitung }}$ & $\mathrm{t}_{\text {tabel }}$ & Ket. \\
\hline Berpikir & Open-ended & 24,06 & \multirow{2}{*}{1,70} & $\mathrm{H}_{0}$ ditolak \\
\cline { 2 - 3 } Kreatif & CTL & 17,66 & & $\mathrm{H}_{0}$ ditolak \\
\hline
\end{tabular}

Berdasarkan Tabel 7 di atas, diperoleh $t_{\text {hitung }}=24,06$ untuk pendekatan open-ended. Jika dikaitkan dengan kriteria pengujian, $t_{\text {hitung }}=24,06>t_{\text {tabel }}=$ 1,70 maka $\mathrm{H}_{0}$ ditolak. Jadi dapat disimpulkan bahwa rata-rata berpikir kreatif siswa yang menggunakan pendekatan openended lebih besar dari 41,70. Dengan kata lain pendekatan open-ended efektif ditinjau dari berpikir kreatif. Sedangkan untuk pendekatan CTL diperoleh $\mathrm{t}_{\text {hitung }}=$ 17,66. Jika dikaitkan dengan kriteria pengujian, $t_{\text {hitung }}=17,66>$ $\mathrm{t}_{\text {tabel }}=1,70$ maka $\mathrm{H}_{0}$ ditolak. Jadi dapat disimpulkan bahwa rata-rata berpikir kreatif siswa yang menggunakan pendekatan CTL lebih besar dari 41,70. Dengan kata lain pendekatan CTL efektif ditinjau dari berpikir kreatif.

Hasil penelitian ini menunjukkan bahwa pendekatan open-ended dan CTL efektif ditinjau dari berpikir kreatif. Hasil penelitian ini sesuai dengan beberapa teori yang menyebutkan bahwa kedua pendekatan ini efektif ditinjau dari berpikir kreatif.

Shimada (1997)menjelaskan bahwa pendekatan open-ended dapat memberi kesempatan kepada siswa untuk memperoleh pengetahuan/pengalaman, menemukan, mengenali, dan memecahkan masalah dengan beberapa teknik sehingga cara berpikir siswa dapat terlatih dengan baik. Sawada (1997) menyebutkan bahwa dengan pendekatan open-ended siswa memiliki kesempatan lebih banyak dalam memanfaatkan pengetahuan dan keterampilan matematik secara komprehensif. Lebih lanjut Sawada (1997) menyebutkan bahwa dengan pendekatan openended siswa dengan kemampuan matematika rendah dapat merespon permasalahan dengan cara mereka sendiri.

Pembelajaran menggunakan pendekatan CTL memberikan peluang pada siswa untuk lebih berperan aktif dalam belajar. Siswa lebih banyak bekerja dan mengalami sendiri setiap detik kegiatan pembelajaran. Siswa bukan lagi sebagai siswa pasif yang hanya menerima pengetahuan dari guru semata. Ini serupa dengan penjelasan Sagala (2011) bahwa proses pembelajaran CTL berlangsung alamiah dalam bentuk kegiatan siswa bekerja dan mengalami, bukan transfer pengetahuan dari guru ke siswa, strategi pembelajaran lebih dipentingkan pada hasil, dimana siswa belajar mengkonstruksi sendiri. 
Miller (Mahfudy, Budiyono, \& Sutrima, 2011) menjelaskan bahwa pembelajaran kontekstual yang aktif mampu menghasilkan pemahaman konsep yang lebih mendalam, kemandirian siswa, siswa yang lebih bertanggung jawab, kemampuan lebih dalam menghadapi ambiguitas, menunjukkan kemampuan pemecahan masalah dan pengambilan keputusan, berani mengambil resiko, mengambil inisiatif, menunjukkan perilaku kepemimpinan dan membangun tim. Hasil penelitian yang dilakukan Sulianto (2011) menjelaskan bahwa pendekatan open-ended dan CTL memberikan kesempatan kepada siswa untuk menginvestigasi berbagai strategi dan cara yang diyakininya sesuai dengan kemampuan memecahkan masalah sehingga kemampuan berpikir matematika siswa dapat berkembang secara maksimal.

Berdasarkan uraian di atas, jelas bahwa pendekatan openended dan CTL dapat diterapkan untuk memaksimalkan kemampuan berpikir kreatif siswa.

\section{KESIMPULAN DAN SARAN}

Berdasarkan hasil analisis penelitian ini, diperoleh kesimpulan bahwa pendekatan open-ended dan CTL dalam pembelajaran matematika di kelas VII SMP Negeri 1 Sekampung efektif ditinjau berpikir kreatif. Efektivitas tersebut terlihat dari hasil perhitungan one sampel t test seperti tertera pada tabel 7. Secara klasikal rata-rata kemampuan berpikir siswa bagi pada pendekatan open-ended maupun CTL lebih dari 41,70. Hal ini mengindikasikan bahwa rata-rata kemampuan berpikir kreatif masuk dalam kategori cukup kreatif.

Berdasarkan kesimpulan yang telah diuraikan di atas, peneliti memberikan saran sebagai berikut: (1) pembelajaran matematika dengan pendekatan open-ended dan CTL dalam pembelajaran matematika SMP sama-sama efektif ditinjau dari berpikir kreatif, sehingga disarankan agar menerapkannya dalam pembelajaran matematika SMP secara bergantian; peneliti berikutnya disarankan agar memperluas materi yang digunakan dalam penelitian sehingga memungkinkan generalisasi yang luas serta dapat menerapkan di sekolah yang berjenjang lebih tinggi (SMA/sederajat); dan (3) sebelum menerapkan kedua pendekatan ini, alangkah lebih baiknya bila siswa dilatih sedikit demi sedikit menyelesaikan soal yang memiliki kemungkinan banyak jawaban atau banyak cara dan berkaitan dengan kehidupan sehari-hari siswa.

\section{DAFTAR PUSTAKA}

Azwar, S. 2011. Sikap manusia teori dan pengukurannya. Yogyakarta: Pustaka Pelajar. 
Jhonson, Elanie B. 2002. Contextual teaching and learning. (Terjemahan Ibnu Setiawan) Bandung: Kaifa. (Buku asli diterbitkan tahun 2000).

Laila, N. A. 2009. Pengaruh pendekatan ctl terhadap hasil belajar membaca pemahaman bahasa Indonesia siswa kelas IV SD. Cakrawala Pendidikan, November 2009, Th. XXVIII, No. 3

Mahfudy, S., Budiyono, \& Sutrima. 2011. Eksperimentasi pembelajaran ctl dan pembelajaran langsung yang berbasis assessment for learning dalam meningkatkan prestasi belajar matematika SMP ditinjau dari tingkat kreativitas siswa. Prosiding, Seminar Nasional Matematika diselenggarkan oleh FMIPA UNY, pada Juli 2011.

Mahmudi, A. 2008. Tinjauan Kreativitas Dalam Pembelajaran Matematika. Jurnal Pythagoras Volume 4, Nomor 2, Desember 2008

McGregor, D. 2007. Developing thinking developing learning: a guide to thinking skills in education. Poland: Open University Press.

Sagala, S. 2011. Konsep dan makna pembelajaran. Bandung: Alfabeta.

Sawada, T. 1997. Developing lesson plans. The OpenEnded Approach: A New Proposal for Teaching Mathematics (pp. 23 - 35). Reston, VA: NCTM.

Shimada, S. 1997. The Significance of an OpenEnded Approach. Dalam J. P. Becker dan S. Shimada(ed) The OpenEnded Approach: A New Proposal for Teaching Mathematics. NCTM. 1 - 9

Sulianto, J. 2011. Keefektifan model pembelajaran kontekstual dengan pendekatan open-ended dalam aspek penalaran dan pemecahan masalah pada materi segitiga di kelas VII [Versi elektronik]. Diambil pada tanggal 21 Januari 2013, dari http://www.google.com/url $? \mathrm{q}=\mathrm{http}: / / \mathrm{e}-$ jurnal.ikippgrismg.ac.id/in dex.php/malihpeddas/articl e/download/64/56\&sa=U\& ei=4NREUvPCJcH3rQedx 4CQBg\&ved $=0 \mathrm{CB} 0 \mathrm{QFj} \mathrm{AB}$ $\underline{\text { \&sig } 2=5 \mathrm{FwDsbwseN} 8 \mathrm{~V} 0}$ 
e-ISSN 2442-5419 Vol. 5, No. 1 (2016) 13-24

Gazruwwg\&usg=AFQjCN

EP7dBJxgbdWALh5isT8

z2x_MDYQ.

Wang, A.Y. 2011. Contexts of creative thinking: A comparison on creative performance of student teachers in Taiwan and the United States. Journal of International and crosscultural studies, Vol.2, Issue 1, 2011. 